\title{
Radiocarbon
}

\section{Proceedings of the 10th}

\section{International Radiocarbon Conference}

\section{Bern/Heidelberg, 19-26 August 1979}

Radiocarbon, Volume 22, Numbers 2 \& 3, $1980 @ \$ 60.00$

Please order from: Radiocarbon

Kline Geology Laboratory

Yale University

PO Box 6666

New Haven, CT 06511 


\section{CONTENTS}

I James Buckley and Cynthia Valdes-Pages

Teledyne Isotopes Radiocarbon Measurements XII

IRPA Michèle Dauchot-Dehon, Mark Van Strydonck, and Jos Heylen

Institut Royal du Patrimoine Artistique

Radiocarbon Dates VIII

ISGS Chao Li Liu and Dennis D Coleman

Illinois State Geological Survey Radiocarbon

Dates VII

Lu Sören Håkansson

University of Lund Radiocarbon Dates XIV

UM

Sharon Crabtree and J J Stipp

University of Miami Radiocarbon Dates XXI

Z Dušan Srdoč, Adela Sliepčevic, Bogomil Obelic, and Nada Horvatinčic

Rudjer Boškovič Institute Radiocarbon

Measurements VI

List of Laboratories

Index to Volume 23 